\title{
Ossification of the Sella Turcica and Clinoid Ligments, Case Report, Morphological Study and Literature Review
}

\author{
Osificación de la Silla Turca y Ligamentos Clinoideos, Reporte de un Caso, \\ Estudio Morfológico y Revisión de la Literatura \\ *,** Iván Claudio Suazo Galdames; ",**Daniela Alejandra Zavando Matamala \& ** Ricardo Luiz Smith
}

SUAZO, G. I. C.; ZAVANDO, M. D.A. \& SMITH, R. L. Ossification of the sella turcica and clinoid ligments, a case report, morphological study and literature review. Int. J. Morphol., 26(4):799-801, 2008.

SUMMARY: The morphology of the Sella Turcica is important both as a reference in cephalometric studies and in the pituitary gland, internal carotid artery and cavernous sinus surgical boarding. The present report describes a case of partial ossification of the sella turcica walls in a dry skull of 40-year-old Brazilian individual. We analyze the morphometric characteristics of the region.

KEY WORD: Sella turcica; Pituitary; Carotid aneurysm; Interclinoid ligament.

\section{INTRODUCTION}

The ossification of the sella turcica region (ST) occurs from the pituitary cartilage of cartilaginous neurocranium (Fitzgerald, 1978; Moore, 1988; Gomez-Sanchez et al., 2005). In cephalometry studies, the morphology of the ST sets an important landmark, to assess and monitor normal growth and results of orthodontic treatments (Axelsson et al., 2004).

Melsen (1974) has reported that the bone appositional growth of the anterior wall of the inner surface of the ST stops early in life, while the reabsorption of the rear floor and the wall behind the ST continues for a long period. The ST is circumscribed within the anterior and posterior clinoid processes; variations in shape and size of these processes have been widely documented.

Along with the pterygospinous, pterygoalars and carotico-clinoid ligaments, the interclinoid ligaments comprise a group of intrinsic ligaments of the sphenoid bone. The sella turcica bridge corresponds to the partial or complete ossification of the interclinoid ligaments, as it has been reported by many authors (Tebo, 1968; Kapur et al., 2000; Das \& Paul, 2007). The incidence of the sella turcica bridge ranges from 1.54 to $5.9 \%$ of the population (Busch, 1951; Muller, 1952; Platzer, 1957). Becktor et al. (2000) found a prevalence of $18.6 \%$ of this structure in a sample of 177 subjects with abnormalities in craniofacial development, while Leonardi $e t$ al. (2006) observed a high prevalence, in subjects with anomalies in the dental eruption.
Surgical removal of the anterior clinoid processes to expose of the structures of the cavernous sinus is more difficult when the interclinoid ligament is ossified, due to the established neural and vascular relationships (oculomotor, trochlear, abductor, ophthalmic and mandibular nerves, internal carotid artery, cavernous sinus and coronary sinus) (Ozdogmus et al., 2003).

For Inoue et al. (1990) the presence of ossified interclinoid ligament increases surgery difficulty and risks, especially in the presence of aneurysms. Similar opinion is shared by Linskey et al. (1993) who have conducted an extensive analysis on the risk factors in carotid aneurysm surgery at the intrapetrossus tract.

This paper reports the morphometric characteristics and the morphological analysis of a dry skull with complete ossification of the interclinoid ligaments and partial ossification of the sidewalls of the sella turcica.

\section{CASE REPORT}

During inspection of the dried skulls collection of the Federal University of Sao Paulo (UNIFESP), it was noticed an extensive ossification of the sidewalls of the sella turcica in one of the skulls: 40 year-old male, Brazilian origin, brown colored skin, cause of death: acute lobar pneumonia.

\footnotetext{
" Departamento de Anatomía Normal, Universidad de Talca.

** Departamento de Morfología y Genética. Universidad Federal de Sao Paulo.
} 


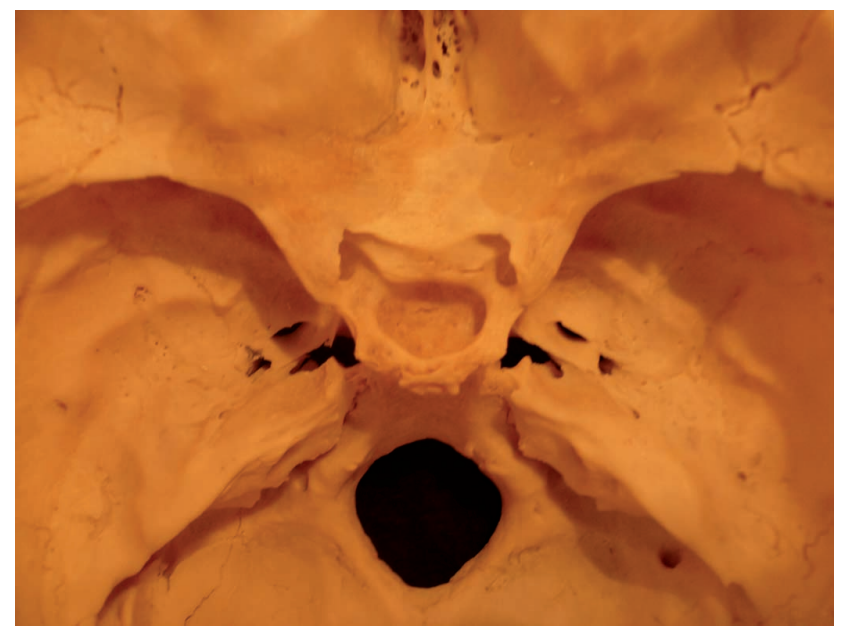

Fig.1 Superior view in the region of the pituitary fossa, anterior clinoid processes (ACP), posterior clinoids processes (PCP) and the interclinoid bony bridges (IC).

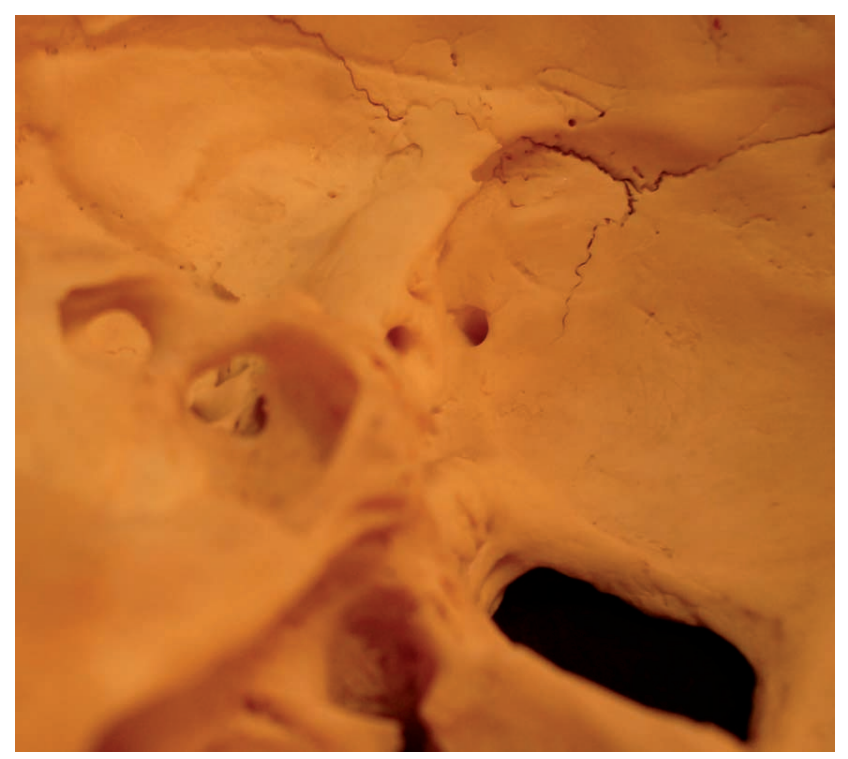

Fig.2 Right sidewall view of the pituitary fossa, carotico-clinoid foramen $(\mathrm{CCF})$ and an irregular drilling in the wall of sella turcica (ST).

At the superior view, a bony bridge links the anterior and posterior clinoid processes, corresponding to the calcification of interclinoids ligament (Fig.1). The morphologic analysis and morphometric descriptions of this structure are described as follows:

Superir view: thickness medial part: $2.16 \mathrm{~mm}$, right side and $2.07 \mathrm{~mm}$, left side, (Fig.1).

Lateral view: right sidewall - an irregular opening was observed, with greater diameter of $5.73 \mathrm{~mm}$, which may have allowed communication between the cavernous sinus and coronary sinus. The carotico-clinoid foramen was also noted, as a pathway for the internal carotid artery (Fig.2).
Left sidewall - intense ossification was observed; a small round foramen, with greater diameter of $2.09 \mathrm{~mm}$ allowed communication between the region of the pituitary fossa and the left cavernous sinus, as on the right side has been formed carotico-clinoid foramen for the passage of the internal carotid artery (Fig.3).

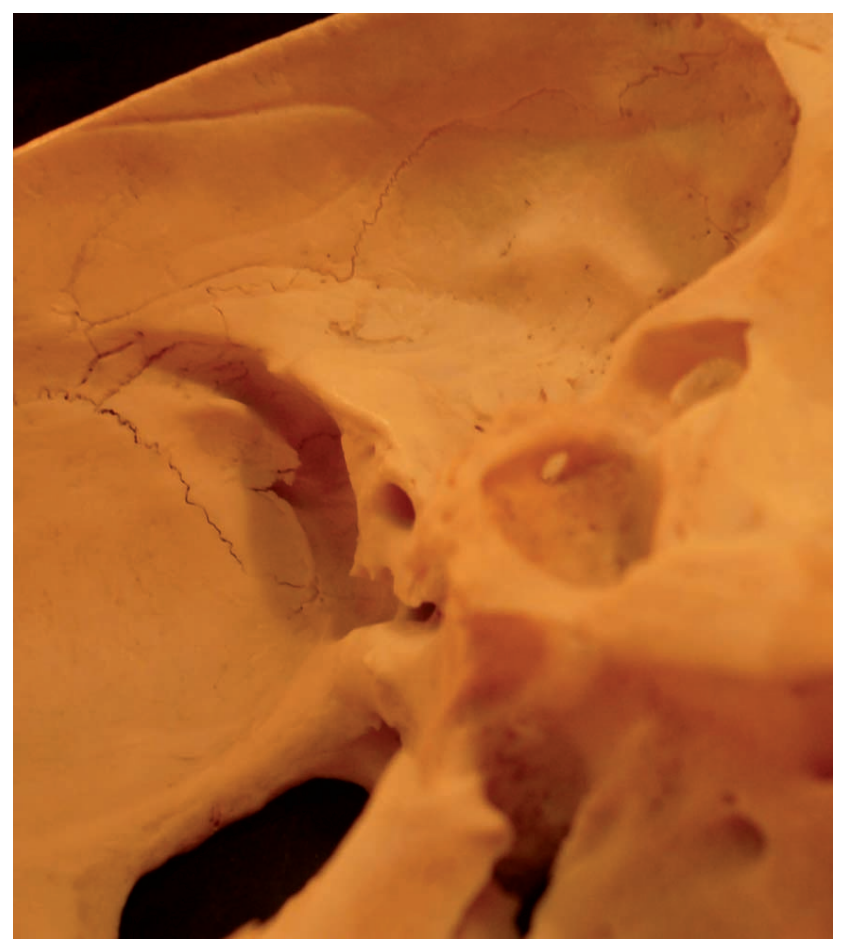

Fig. 3 Left sidewall view of the pituitary fossa, carotico-clinoid foramen $(\mathrm{CCF})$ and a small foramen on the wall of sella turcica wall (ST).

\section{DISCUSSION}

The ossification of the interclinoids ligaments are rare findings and usually asymptomatic. Several authors have reported the presence of these structures in different populations and the incidences are lower than 6\% (Busch; Muller; Platzer). Notwithstanding, an increase prevalence has been reported in subjects with developmental craniofacial and tooth abnormalities (Becktor et al.; Leonardi et al.). In the case that we presented, ossification not only reaches the area of interclinoids and carotico-clinoid ligaments, which also includes side walls of the sella turcica.

We did not find in the literature reports ossification complete or partial as described in this case. This finding has implications in surgical procedures to assess the pituitary gland, cavernous sinus and internal carotid artery at the intracavernous route. 
SUAZO, G. I. C.; ZAVANDO, M. D. A. \& SMITH, R. L. Osificación de la silla turca y ligamentos clinoideos, reporte de un caso, estudio morfológico y revisión de la literatura. Int. J. Morphol., 26(4):799-801, 2008.

RESUMEN: La morfología de la silla turca tiene importancia tanto como referencia en los estudios cefalométricos como en los abordajes quirúrgicos de la glándula hipófisis, carótida interna y seno cavernoso. En el presente reporte se describe un caso de osificación parcial de las paredes de la silla turca, en un cráneo seco de un individuo brasilero de 40 años. Se analizan las características morfométricas de la región.

PALABRAS CLAVE: Silla turca; Hipófisis; Aneurisma carotideo; Ligamento interclinoideo.

\section{REFERENCES}

Axelsson, S.; Storhaug, K. \& Kjær, I. Post-natal size and morphology of the sella turcica. Longitudinal cephalometric standards for Norwegians between 6 and 21 years of age. Eur. J. Orthod., (26):597-604, 2004.

Becktor, J. P.; Einersen, S. \& Kjær, I. A sella turcica bridge in subjects with severe craniofacial deviations. Eur. $J$. Orthod., (22):69-74, 2000.

Busch, W. Die Morphologie der sella turcica und ihre bezeihung zur hypophyse. Virchows Arch., 320:437-58. 1951.

Das, S. \& Paul, S. Ossified pterygospinous ligament and its clinical implications. Bratisl. Lek. Listy., 108(3):141-3, 2007.

Fitzgerald, M. J. T. Human Embryology: A Regional Approach. Baltimore, Harper and Row, 1978.

Gómez-Sánchez, A.; Cortes-González, P.; de la Garza-Castro, O.; Garza-Rodríguez, V.; Muraira-González, J. \& Guzmán-López S. Granuloma eosinófilo en el hueso occipital y la silla turca del mismo paciente. Arch. Neurocien., (10)4:261-3, 2005.

Inoue, T.; Rhoton, A. L. Jr.; Theele, D. \& Barry, M. E. Surgical approaches to the cavernous sinus: a microsurgical study. Neurosurgery, (26):903-32, 1990.

Kapur, E.; Dilberovic', F.; Redzepagic', S. \& Berhamovic', E. Variation in the lateral plate of the pterygoid process and the lateral subzygomatic approach to the mandibular nerve. Med. Arh., 54(3):133-7, 2000.

Leonardi, R.; Barbato, E.; Vichi, M. \& Caltabiano, M. A sella turcica bridge in subjects with dental anomalies. Eur. J. Orthod., (28):580-5, 2006.

Linskey, M. E.; Sekhar, L. N.; Hirsch, W. L.; Yonas, H. \&
Horton, J. A. Aneurysms of the intracavernous carotid artery: History and indications for treatment. Neurosurg, 26: 933-8, 1993.

Melsen, B. The cranial base, the postnatal development of the cranial base studied on human autopsy material. Acta Odontol. Scand., 32, supplement 62, 1974.

Moore, K. L. The developing human: Clinically Oriented Embryology. $4^{\text {th }}$ Ed. Philadelphia, W. B. Saunders, 1988.

Muller, F. Die Bedeutung der sellabruecke fur das Auge. Klin. Monatsbl. Augenheilkd., 120:298-302, 1952.

Ozdogmus, O.; Saka, E.; Tulay, C.; Gurdal, E.; Uzun, I. \& Cavdar, S. Ossification of interclinoid ligament and its clinical Significance. Neuroanatomy, 2:25-7, 2003.

Platzer, W. Zur Anatomie der Sellabruecke und ihrer Bezeihung Zur A. Carotis Interna. Fortschr. Geb. Rontgenstr. Nuklearmed., 87(5):613-6. 1957.

Tebo, H. G. The pterygospinous bar in panoramic roentgenography. Oral Surg Oral Med Oral Pathol., 26:654-7, 1968.

Correspondence to:

Dr. Iván Suazo Galdames

Department of Normal Anatomy

Universidad de Talca

Avenida Lircay s/n Oficina $N^{\circ} 104$

Talca - CHILE

Phone: 56-71-201682

Email: isuazo@utalca.cl

Received: 03-07-2008

Accepted: 02-09-2008 
